\title{
Low control of bacterial production by heterotrophic nanoflagellates in a eutrophic backwater environment
}

\author{
C. Wieltschnig, P. Wihlidal, T. Ulbricht, A. K. T. Kirschner, B. Velimirov* \\ Institut für Medizinische Biologie, Universität Wien, Abteilung Allgemeine Mikrobiologie, Währinger Str. 10, \\ A-1090 Wien, Austria
}

\begin{abstract}
In an investigation in the backwater system of the Alte Donau (Vienna, Austria) on the impact of heterotrophic nanoflagellates (HNF) as bacterivores and on their role in the pelagic carbon cycle, it was shown that from April 1995 to June 1996. HNF abundance ranged from $0.2 \times 10^{2}$ to $39.2 \times$ $10^{2}$ cells ml-1, with a yearly mean of $5.8 \times 10^{2}$ cells ml ${ }^{-1}$ Mean HNF biomass was $7.4 \mu \mathrm{g} \mathrm{Cl}^{-1}$, ranging from 0.1 to $41.1 \mathrm{\mu g} \mathrm{C}^{-1}$. Ingestion rates on heterotrophic bacteria, estimated on the basis of uptake of fluorescently labeled bacteria, were 2.2 to 26.5 cells $\mathrm{HNF}^{-1} \mathrm{~h}^{1}$ (mean: 7.5 cells $\mathrm{HNF}^{-1} \mathrm{~h}^{-1}$ ). Resulting grazing rates only made up between 0.3 and $20 \%$ (mean: $5 \%$ ) of bacterial secondary production, and it was evident that heterotrophic nanoflagellates were not able to control bacterial production, indicating that factors other than HNF grazing must play an important role for the mortality of bacteria in the investigated system. A consequence of the fact that only a mean of $0.09 \mu \mathrm{g}$ bacterial carbon $\mathrm{l}^{-1} \mathrm{~h}^{-1}$ was consumed by HNF was that transfer of picoplanktonic carbon to higher trophic levels via HNF was negligible. HNF could not function as a link between the microbial compartment and the classical pelagic food chain, even if nanoflagellates themselves were under strong predatory control, which was indicated by experiments conducted to compare flagellate gross and net growth rates. Another finding was that HNF covered only a mean of $21 \%$ of their carbon demand by the consumption of bacteria, despite high abundance of bacterial carbon as a food source. The error potential of the applied methods was estimated in view of the carbon budget of the bacteria-HNF interaction. This still implied that HNF had to use other carbon sources to a remarkable degree in order to maintain production. The possibility that dissolved organic matter (DOM) may represent a major energy source covering HNF carbon demand is discussed.
\end{abstract}

KEY WORDS: Heterotrophic nanoflagellates - Fluorescently labeled bacteria Carbon flow Bacterial production - Bacterivory - Eutrophic backwater systems

\section{INTRODUCTION}

Planktonic bacteria have the potential for rapid growth; however, bacterial numbers vary by less than 1 order of magnitude over the course of a year in pelagic ecosystems (Cole \& Caraco 1993). Even when large increases in phytoplankton biomass and production take place, relatively small increases in bacterial numbers are usually observed (Ducklow \& Carlson 1992, del Giorgio \& Gasol 1995), and the bacterial com-

-Addressee for correspondence.

E-mail: branko.velimirov@univie.ac.at partment is considered as the least variable component of the plankton in terms of density and biomass (del Giorgio et al. 1996). Therefore the investigation of processes which balance bacterial production is of major importance to track the pathways of bacterial carbon and understand the principles of carbon flow within the microbial loop.

Heterotrophic nanoflagellates (HNF) in the size range of 2 to $20 \mu \mathrm{m}$ have been identified as efficient bacterivores in most aquatic environments (Fenchel 1982b, Sherr et al. 1987. Weisse 1989). Thus they are expected to play a key role in controlling bacterial production (Bloem \& Bär-Gilissen 1989, Fukami et al. 
1991, del Giorgio et al. 1996), and as it is now well known that HNF are an important food source for larger protozoans and metazoans, they should function as a link between the microbial compartment and higher trophic levels (Carrick et al. 1991, Dolan \& Gallegos 1991, Weisse 1991, Jürgens \& Stolpe 1995, Jürgens et al. 1996).

However, there are studies revealing obvious discrepancies between bacterial production and grazing losses inflicted by HNF (Sanders et al. 1989, Sherr et al. 1989, Vaqué \& Pace 1992, Pernthaler et al. 1996), indicating a lack of coupling between bacteria and HNF across aquatic systems (Gasol \& Vaqué 1993). Especially in eutrophic systems, HNF might not be able to play the role which has commonly been ascribed to them. Recent literature suggests that in some eutrophic waters grazing pressure on these protozoans is too strong to lead to HNF abundances which can affect bacterial numbers (Gasol 1994, Gasol et al. 1995, Pace \& Cole 1996). Aiternatively, the loose correlation between bacteria and HNF may also be due to the fact that natural HNF do not always efficiently exploit heterotrophic bacteria as a food source (Jürgens 1992), which could be explained by the presence of grazingresistant bacteria (Jürgens \& Güde 1994) or of nonbacterivorous HNF groups within the natural assemblage or by the dominance of HNF species which cover their carbon demand by tapping other carbon sources than bacteria (Šimek \& Straškrabová 1992). Phagotrophic protozoa may ingest autotrophic picoplankton (Nagata 1988, Pernthaler et al. 1996), viruses (Gonzales \& Suttle 1993), phytoplankton detritus (Van Wambeke 1994) and dissolved organic matter (Sherr 1988, Tranvik et al. 1993, Christoffersen et al. 1996). It was therefore plausible to assume that mechanisms which regulate heterotrophic microbial population densities differ between systems.

The present investigation was part of a carbon flow study within the microbial loop and took place in the pelagial of a eutrophic freshwater system, the Alte Donau, belonging to the backwater system of the River Danube. The aim of the investigation was to further examine whether HNF function as bacterivores in this eutrophic system by (1) quantifying the contribution of HNF grazing to bacterial mortality and (2) determining to which degree HNF carbon demand is covered by bacterial ingestion. We concurrently monitored abundances, biomass, and production of bacteria and HNF over 1 yr and conducted experiments to estimate in situ growth and grazing rates of HNF using fluorescently labeled bacteria (Sherr et al. 1987).

Our results indicated that for the investigated system, HNF played a negligible role in controlling bacterial production, and against expectations, they were not relying primarily on bacteria to cover their carbon demand, despite high abundance of this potential food source.

\section{MATERIALS AND METHODS}

Study site and sampling. Sampling was conducted at 4 sampling stations, designated as Stn A (6 m depth), Stn B (3.5 m depth), Stn C (3 m depth) and Stn D (3 m depth), in the Alte Donau, a eutrophic backwater of the River Danube (Vienna, Austria), on 24 occasions between April 1995 and June 1996 (Fig. 1). Mean chlorophyll a concentration in this system was $12.0 \mathrm{\mu g} \mathrm{l}^{-1}$ in 1995 and $12.6 \mathrm{\mu g} \mathrm{l}^{-1}$ in 1996, mean total phosphorus concentration was 27 and $19 \mu \mathrm{g} \mathrm{I}^{-1}$, mean total nitrogen concentration was 1.88 and $0.94 \mathrm{mg} \mathrm{l}^{-1}$, mean POM concentration was 8.1 and $6.4 \mathrm{mg} \mathrm{l}^{-1}$, and mean DOC. concentration was 3.1 and $2.5 \mathrm{mg} \mathrm{l}^{-1}$ for the 2 yr of investigation (unpubl. data). From April to October, samples were taken biweekly, and in winter, 1 sample was taken every 4 to $6 \mathrm{wk}$. At each sampling event, temperature and oxygen profiles were measured with a multiple parameter probe (Hydrolog 2100, Grabner Instruments).

Between 09:00 and 11:00 h samples were taken with a Schindler sampler (UWI-Tec Mondsee). One integrated sample was taken for the upper half of the water column (sampling interval $0.5 \mathrm{~m}$ ), and 1 for the lower half (sampling interval $0.5 \mathrm{~m}$ ) in consideration of possible oxygen deficiency in the lower water column causing stratification of HNF densities. All samples were brought to the laboratory within $1 \mathrm{~h}$.

Staining, enumeration and size measurements of HNF and bacteria. Samples were fixed with formaldehyde (final concentration $1.85 \%$ ) and stored at $4^{\circ} \mathrm{C}$. All samples were processed within less than 1 wk. For enumeration of HNF, subsamples of 10 to $40 \mathrm{ml}$ were stained with 4'6-diamidino-2-phenylindole (DAPI) (Porter \& Feig 1980) and examined by epifluorescence microscopy. As many HNF may have lost their flagella upon fixation and filtration, not only were nanoplankton with visibly attached flagella counted, but all intact nanoplanktonic cells with a nucleus were judged as nanoflagellates. Phototrophic flagellates could be distinguished from HNF by their red-orange autofluorescence. For estimation of bacterial number (BN) the acridine-orange direct count method according to Hobbie et al. (1977) was applied.

HNF and bacterial cells were sized by eyepiece micrometer. For HNF, linear dimensions (length and width) of at least 50 cells were measured. Estimates by eye were controlled by a semi-automatic image analyser (LeitzASM 68K) on magnifications of epifluorescence photomicrographs. Further calculations were based on estimates by eyepiece micrometer, because this turned out 
to be the fastest method for routine measurements, while image analysis was mainly used for control. Cell volumes were calculated assuming either a spherical or elliptical cell shape (Fenchel 1982b, Nagata 1988). Bacterial cell volume estimations were based on the assumption that all bacteria are spheres or cylinders with 2 hemispherical caps. Fluorescent latex beads with diameters of $0.11,0.22,0.66$, and $0.88 \mu \mathrm{m}$ (Polyscience, Inc.) were used for calibration of the sizing procedure with an automatic image analyser (Leitz-ASBA III) (Velimirov \& Walenta-Simon 1992). Cellular carbon content for HNF was calculated from estimated mean cell volumes assuming a conversion factor of $0.22 \mathrm{pg} \mathrm{C} \mathrm{mm}^{-3}$ for preserved cells after Børsheim \& Bratbak (1987). For bacteria, the allometric relation $C=120 \times V^{0.72}$ according to Norland (1993) was applied (C: cellular carbon content in $\mathrm{fg}$ C cell ${ }^{-1} ; V$ : cell volume in $\mu \mathrm{m}^{3}$ )

HNF growth rates. On 5 occasions in 1996 (4 March, 23 April, 18 June, 30 July and 23 October) HNF secondary production was measured applying selective filtration. As no stratification could be observed during the whole sampling period (see 'Results'), an integrated water sample from Stn B was immediately gravity filtered through a $10 \mu \mathrm{m}$ mesh size gauze to remove potential predators of HNF. The filtered water was incubated in duplicate $2.5 \mathrm{l}$ clear polycarbonate bottles, which were exposed for $48 \mathrm{~h}$ at $1.5 \mathrm{~m}$ depth at the sampling station. During the incubation period, subsamples of $20 \mathrm{ml}$ were taken in intervals ranging from 12 to $24 \mathrm{~h}$ and fixed immediately with formaldehyde. Determination of HNF abundance (HNFA) and biomass was carried out as described above. HNF growth rates $(\mu)$ and generation times $(t)$ were based on changes in abundance or biomass for the time interval during which exponential growth was observed.

Parallel to the last 2 growth experiments a diurnal course of HNF abundance and biomass was performed. For this purpose integrated samples from Stn B were taken over $24 \mathrm{~h}$, from 06:00 to $06.00 \mathrm{~h}$ in intervals of $4 \mathrm{~h}$. Samples were brought to the laboratory immediately, fixed (formaldehyde, final concentration $1.85 \%$ ) and HNF abundance and biomass were determined as described above.

Grazing on bacteria. Twelve experiments to estimate grazing rates of HNF on bacteria under in situ temperature conditions were carried out from August 1995 to December 1996 by using fluorescently labeled bacteria (FLB) (Sherr et al. 1987).

FLB were prepared from bacteria from Stn B by filtration of a sample through a $1.2 \mu \mathrm{m}$ pore size polycarbonate filter (Millipore) and by incubating about $500 \mathrm{ml}$ of the filtered bacterial suspension with a wheat grain in a sterilized glass bottle at room temperature (R. Sommaruga pers. comm.). This resulted in a small, but insignificant, increase in bacterial cell size, but the morphological diversity of the natural bacterial community was preserved. In late logarithmic phase the bacteria were concentrated by centrifugation (Sorval Instruments RC5C, $13400 \mathrm{rpm}[26000 \times \mathrm{g}$ ] for 20 min at $\left.4^{\circ} \mathrm{C}\right)$ and stained with 5 - $([4,6$-dichlorotriazin2-yl]amino)fluorescein (DTAF) as described by Sherr et al. (1987). Instead of sonication a few minutes of vibration with a test tube mixer (Janke \& Kunkel VF2) was used to disintegrate bacterial clumps. Before storing the FLB suspension, it was again filtered through a $2 \mu \mathrm{m}$ pore size polycarbonate filter (Millipore) to remove remaining bacterial clumps and to reduce the amount of potentially grazing-resistant filamentous bacteria.

For each experiment, triplicates of an integrated sample from Stn B were incubated in Erlenmeyer flasks in a water bath at in situ temperature and FLB 
were added into the experimental flask at concentrations of about $25 \%$ of natural bacteria (Sherr et al. 1987). Subsamples were taken after 2 and 5 min and then every 5 min and fixed immediately with formaldehyde $(1.85 \%$ final conc.). The last subsamples were taken after $20 \mathrm{~min}$.

A minimum of 50 flagellates were inspected for each subsample. FLB within each flagellate were enumerated by switching the filter sets from DAPI to DTAF fluorescence. DAPI staining did not interfere with the DTAF staining of the FLB, so they could be easily distinguished in HNF cells. The average number of FLB per cell was then calculated as the total number of FLB ingested divided by the total number of HNF examined. Ingestion rates of FLB were calculated from the linear portion of the uptake curves on the basis of linear regression analysis of the number of FLB per flagellate (mean of triplicate samples) against time (McManus \& Fuhrman 1986, Sherr et al. 1987, Bloem et al. 1989). One basic condition of this model is that uptake of fluorescent bacteria at time zero is zero. So an initial uptake rate of $0 \mathrm{FLB} \mathrm{HNF}^{-1}$ was added to the data series.

As it is sometimes difficult to decide if a flagellate really contains FLB or the stained bacteria just landed on top of the protozoan cell after filtration, 3 control experiments were carried out to correct for this background. Control experiments were conducted as the other experiments, except that the water sample was fixed with formaldehyde before addition of FLB to prevent uptake of FLB by HNF. The average number of FLB per cell was calculated as described above, and the data from the 12 uptake experiments were corrected with the value obtained in the control experiments for the estimation of ingestion rates.

Bacterial secondary production. Bacterial secondary production (BSP) was determined by the ${ }^{14} \mathrm{C}$ leucine incorporation method according to Simon \& Azam (1989). $10 \mathrm{ml}$ triplicates of each sample were dispensed into a series of $20 \mathrm{ml}$ polyethylene vials and supplemented with a constant amount of ${ }^{14} \mathrm{C}$-leucine (final concentration: 40 to $60 \mathrm{nM}_{\mathrm{i}} 325 \mathrm{Ci} \mathrm{mmol}^{-1}$; NENResearch Products). The appropriate concentrations were seasonally evaluated by saturation experiments and values were well in agreement with concentrations obtained for other eutrophic environments (Van Looij \& Riemann 1993). Briefly, all samples were incubated for $30 \mathrm{~min}$ at in situ temperature, triplicate blanks were killed with formaldehyde (final concentration: $4 \%$ ) prior to incubation. After the addition of $500 \mu \mathrm{I} \mathrm{TCA}$ $(100 \%)$ the samples were boiled for $30 \mathrm{~min}$ to solubilize DNA and the precipitated proteins were collected on $0.1 \mu \mathrm{m}$ membrane filters (Sartorius). The filters were then put into $7 \mathrm{ml}$ scintillation vials, $5 \mathrm{ml}$ of scintillation cocktail (Filter count, Canberra Packard) was added, and the radioactivity on the filters was determined in a scintillation counter (Canberra Packard 1900 TR). Rates of ${ }^{14} \mathrm{C}$-leucine incorporation were converted to bacterial C production according to Simon \& Azam (1989). The obtained values were converted into bacterial cell production by division through the estimated mean cellular carbon content per samping event.

In order to test the reliability of the leucine incorporation method for the quantification of bacterial production in our system, preliminary test series were performed from April to November 1994. Over this period all samples $(n=45)$ were accompanied by parallel triplicate subsamples labeled with ${ }^{3} \mathrm{H}$-thymidine according to the procedure described in detail by Kirschner \& Velimirov (1997). The obtained thymidine incorporation values ( $\mathrm{pmol} \mathrm{l}^{-1} \mathrm{~h}^{-1}$ ) were converted into cell production by using a conversion factor of $2.8 \times 10^{6}$ cells $\mathrm{pmol}^{-1}$ empirically derived for another branch of the same backwater system (Mathias et al. 1995).

Statistical analysis. Data were analysed according to Zar (1974) and Sachs (1992). The statistical software SPSS 6.0.1 1994 and STATISTICA 4.01993 was used. Differences between sampling stations were analysed by Kruskal-Wallis 1-way ANOVA. Correlations between variables were calculated using the non parametric Spearman rank sum test. Regression analysis was applied to calculate ingestion and growth rates. Even distribution of HNF abundance and biomass over diurnal courses was tested by Kolmogoroff-Smirnoff goodness of fit test. All statistical analysis was accepted as significant at a probability level of $p \leq 0.05$.

Table 1. Range of heterotrophic nanoflagellate abundance, cell length, ceil voiume and biondss úurily the iñvestigatioñ pêriod (19 April 1995 to 18 June 1996). Numbers in parentheses denote 1 SD

\begin{tabular}{|c|c|c|c|c|c|c|c|c|c|}
\hline \multirow[t]{2}{*}{$\begin{array}{l}\text { Sampling } \\
\text { station }\end{array}$} & \multicolumn{2}{|c|}{$\begin{array}{c}\text { Abundance } \\
\left(10^{2} \text { cells } \mathrm{ml}^{-1}\right)\end{array}$} & \multicolumn{2}{|c|}{$\begin{array}{l}\text { Cell length } \\
(\mu \mathrm{m})\end{array}$} & \multicolumn{2}{|c|}{$\begin{array}{l}\text { Cell volume } \\
\left(\mu \mathrm{m}^{3}\right)\end{array}$} & \multicolumn{2}{|c|}{ 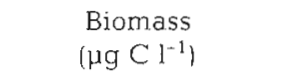 } & \multirow[t]{2}{*}{$\mathrm{n}$} \\
\hline & Mean & Range & Mean & Range & Mean & Range & Mean & Range & \\
\hline A & $6.5(5.1)$ & $1.4-20.4$ & $5.7(1.1)$ & $3.5-7.6$ & $61.9(31.1)$ & $17-150$ & $7.9(7.1)$ & $2.3-29.3$ & 24 \\
\hline$B$ & $6.7(7.7)$ & $1.4-39.2$ & $5.9(1.1)$ & $3.4-8,0$ & $63.7(28.0)$ & $17-210$ & $9.5(10.5)$ & $2.2-41.1$ & 24 \\
\hline C & $4.7(3.9)$ & $0.2-17.9$ & $5.5(1.0)$ & $3.3-7.2$ & $54.4(22.4)$ & $13-116$ & $5.6(5.3)$ & $0.2-20.8$ & 24 \\
\hline $\mathrm{D}$ & $5.3(6.1)$ & $0.2-25.3$ & $5.5(1.2)$ & $3.1-7.8$ & $53.8(26.3)$ & $12-120$ & $6.5(8.5)$ & $0.1-30.5$ & 24 \\
\hline
\end{tabular}



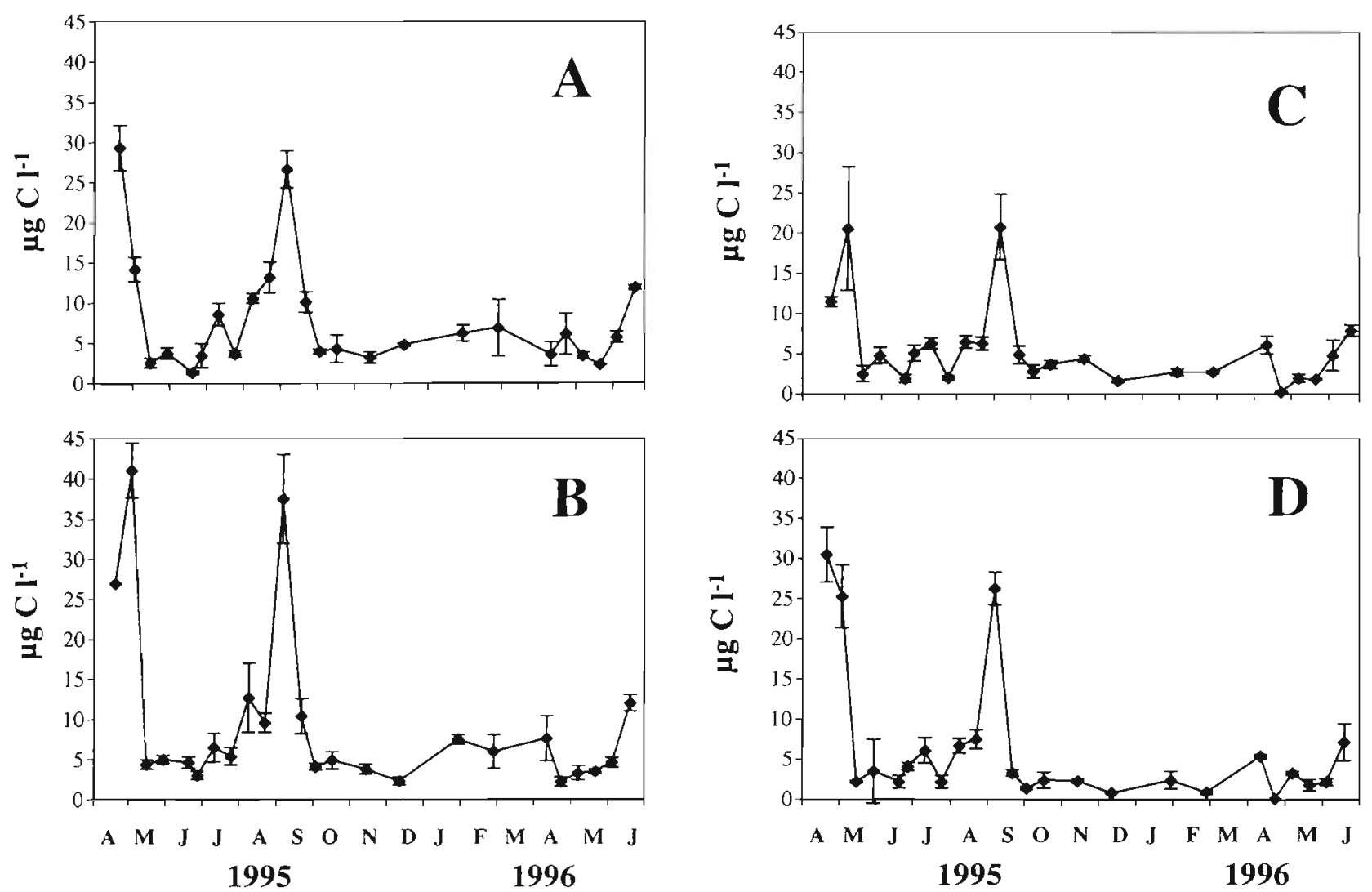

Fig. 2. Annual course of heterotrophic nanoflagellate biomass in sampling stations A to D from 19 April 1995 to 18 June 1996 . Error bars indicate 1 standard deviation of pooled samples

\section{RESULTS}

Water temperatures ranged from $1^{\circ} \mathrm{C}$ in winter to $25^{\circ} \mathrm{C}$ in summer time. Thermal stratification could not be observed in any sampling station during the investigation period. Oxygen profiles were similar for all sampling stations, indicating no oxygen deficiency throughout the water column, except on 4 occasions in summer 1995, when oxygen saturation was only around $50 \%$ in the lower water column of Stn D (data not shown).

\section{HNF and bacterial abundances}

Annual mean HNF abundance was $6.5 \times 10^{2}( \pm 5.1)$, $6.7 \times 10^{2}( \pm 7.7), 4.7 \times 10^{2}( \pm 3.9)$, and $5.3 \times 10^{2}( \pm 6.1)$ cells $\mathrm{ml}^{-1}$ at Stns $\mathrm{A}, \mathrm{B}, \mathrm{C}$, and D, respectively, with cell numbers ranging from $0.2 \times 10^{2}$ to $39.2 \times 10^{2} \mathrm{ml}^{-1}$ in the Alte Donau (Table 1). As temperature and oxygen measurements indicated homogenous conditions throughout the water column, data obtained from counts for the upper and lower water column were pooled.

Bacterial numbers ranged from $0.98 \times 10^{6}$ to $5.59 \times$ $10^{6}$ cells $\mathrm{ml}^{-1}$ over the entire investigation period in the Alte Donau. No statistically significant correlation was detected between HNF and bacterial time courses (data not shown) in any of the surveyed stations ( $S t n A, r=0.17, p>0.40 ; \operatorname{Stn} B, r=0.26, p>$ $0.20 ; \operatorname{Stn} C, r=0.24, p>0.25 ; \operatorname{Stn} D, r=0.19, p>$ $0.35)$.

\section{HNF biomass}

HNF biomass in the Alte Donau ranged from 0.1 to $41.1 \mu \mathrm{g} \mathrm{Cl}^{-1}$, with a mean of $7.9( \pm 7.1), 9.5( \pm 10.5), 5.6$ $( \pm 5.3)$, and $6.5( \pm 8.5) \mu \mathrm{g} \mathrm{Cl}^{-1}$ for the sampling stations (Table 1). Fig. 2 shows that in spring 1995 a peak in HNF biomass could be observed which was due to a peak in HNF numbers rather than large cell volumes. Thereafter biomass drastically decreased. In September 1995 the HNF assemblage was dominated by large cells, resulting in a remarkable increase in biomass. During this late summer peak HNF biomass nearly reached the values of April-May 1995. Throughout autumn and winter biomass remained low due to small cell size. In spring 1996 no peak occurred as a result of low HNF numbers, with values increasing only at the end of the investigation period. 
Table 2. Growth parameters of the nanoflagellate assemblage at Stn B based on cell number and biomass. $t_{0}$ : beginning of exponential growth $t_{x}$ : end of exponential growth

\begin{tabular}{|c|c|c|c|c|c|c|c|c|c|c|}
\hline \multirow[t]{3}{*}{ Date } & \multirow{3}{*}{$\begin{array}{l}\text { Water } \\
\text { temp. } \\
\left({ }^{\circ} \mathrm{C}\right)\end{array}$} & \multirow{3}{*}{$\begin{array}{l}\text { Duration } \\
\text { expon. } \\
\text { growth } \\
\text { (h) }\end{array}$} & \multirow{2}{*}{\multicolumn{2}{|c|}{$\begin{array}{l}\text { Cell number } \\
\left(10^{2} \mathrm{ml}^{-1}\right)\end{array}$}} & \multirow{2}{*}{\multicolumn{2}{|c|}{$\begin{array}{c}\text { Biomass } \\
\left(\mu \mathrm{g} \mathrm{Cl}^{-1}\right)\end{array}$}} & \multicolumn{2}{|c|}{ Growth rate $(\mu)$} & \multicolumn{2}{|c|}{ Generation time } \\
\hline & & & & & & & Cell & Biomass & Cell & Biomass \\
\hline & & & $t_{0}$ & $t_{x}$ & $t_{0}$ & $t_{x}$ & $\left(h^{-1}\right)$ & $\left(h^{-1}\right)$ & (h) & (h) \\
\hline $4 \operatorname{Mar} 96$ & 6 & 24 & 3.38 & 4.48 & 3.21 & 6.16 & 0.013 & 0.027 & 53 & 26 \\
\hline 11 Apr 96 & 14 & 48 & 2.62 & 1.10 & 4.39 & 1.65 & - & - & - & - \\
\hline 4 Jun 96 & 22 & 48 & 1.48 & 7.18 & 1.98 & 9.27 & 0.034 & 0.033 & 20 & 21 \\
\hline $30 \mathrm{Jul} 96$ & 23 & 24 & 3.86 & 5.84 & 5.33 & 10.67 & 0.017 & 0.029 & 40 & 24 \\
\hline 23 Oct 96 & 12 & 24 & 5.79 & 7.54 & 10.18 & 13.89 & 0.012 & 0.014 & 60 & 51 \\
\hline
\end{tabular}

\section{HNF secondary production}

The growth parameters (mean of duplicate samples) determined for Stn B are shown in Table 2. Growth rates ranged trom $0.012 \mathrm{~h}^{-\mathrm{i}}$ to $0.034 \mathrm{~h}^{-1}$, with slowest growth at low temperatures (Table 2). On 23 April 1996 the incubated sample was possibly contaminated with predators on HNF because values for HNF abundance and HNF biomass fluctuated during the incubation time of $48 \mathrm{~h}$ with no clear positive or negative trend. Consequently, growth rates could not be calculated. In March, April, June and October mean cell volumes did not change significantly during the incubation period ( $p>0.40,0.35,0.10$ and 0.70 ). During the experiment in July, mean cell volume significantly increased ( $p<$ 0.03 ), which resulted in a growth rate based on biomass which was nearly twice as high as the one calculated on the basis of increase in cell number (Table 2).

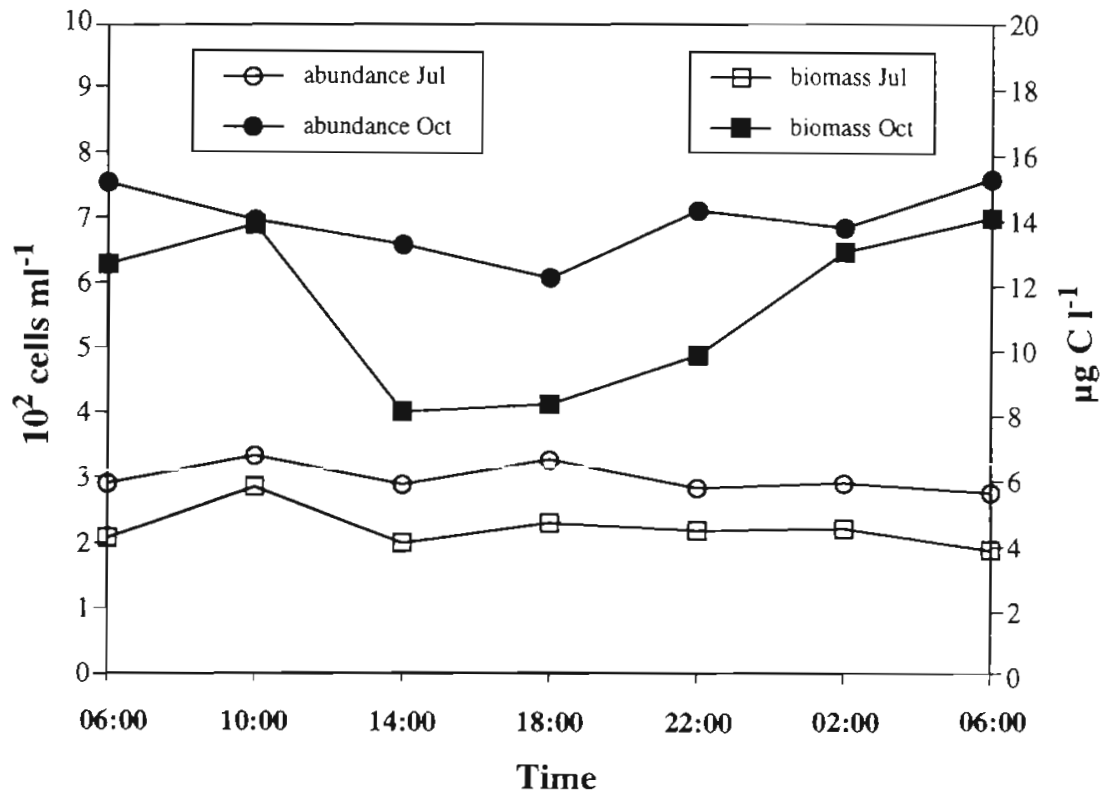

Fig. 3. Diurnal courses of heterotrophic nanoflagellate abundance $(0,0)$ and biomass $(\square, \boldsymbol{\omega})$ on 30 July (open symbols) and 23 October (filled symbols)
The diurnal courses of HNF numbers and biomass during the experiments in July and October are shown in Fig. 3. Compared to gross growth in the filtered samples used in growth experiments, abundance and biomass did not change significantly over $24 \mathrm{~h}$ in the water column. Neither during the experiment in July nor during the one in October could net increase in HNF cell numbers ( $p>0.10$ and 0.85 ) and biomass ( $p>$ 0.10 and 0.75 ) or significant changes in mean cell volume ( $p>0.75$ and 0.35 ) be observed.

\section{Bacteria}

Bacterial numbers (BN), estimated for the occasions when HNF grazing rates were estimated, ranged from $1.30 \times 10^{6}$ to $4.71 \times 10^{6}$ cells $^{-1}$ (Table 3 ). Highest values were observed in August and November 1995 , then cell numbers constantly decreased to reach a minimum value of $1.30 \times 10^{6}$ cells $\mathrm{ml}^{-1}$ on 23 April 1996. A slight increase in $B N$ was noticed for May to September, and in late autumn and winter 1996 cell densities had reached similar values to autumn and winter 1995. Bacterial biomass showed a similar time course to abundance, with values ranging from 29.0 to $79.3 \mu \mathrm{g} \mathrm{C} \mathrm{l}^{-1}$ (Table 3). When comparing the preliminary test series data of hacterial secondary production derived from the ${ }^{3} \mathrm{H}$-thymidine and the ${ }^{14} \mathrm{C}$-leucine incorporation, a highly significant positive correlation was found $(\mathrm{r}=0.70 ; \mathrm{p}<$ $0.001 ; \mathrm{n}=45$ ). During this test series production, data obtained by the thymidine method varied between 0.98 and $11.62 \mu \mathrm{g} \mathrm{C} \mathrm{I}^{-1} \mathrm{~h}^{-1}$ (mean: $3.79 \mu \mathrm{g}$

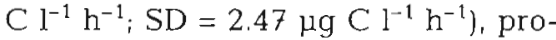
duction data obtained by the leucine 
method varied between 1.0 and $7.9 \mu \mathrm{g} \mathrm{Cl}^{-1} \mathrm{~h}^{-1}$ (mean: $3.26 \mu \mathrm{g} \mathrm{Cl}^{-1} \mathrm{~h}^{-1} ; \mathrm{SD}=1.58 \mu \mathrm{g} \mathrm{Cl}^{-1} \mathrm{~h}^{-1}$ ). The calculated leucine/thymidine ratio amounted on average to 0.98 $(\mathrm{SD}=0.52)$, indicating an acceptable correspondence between the 2 methods. During the investigation period bacterial secondary production (BSP) estimated with the ${ }^{14} \mathrm{C}$-leucine method was on average $2.18 \mu \mathrm{g} \mathrm{C}$ $\mathrm{l}^{-1} \mathrm{~h}^{-1}$. In August 1995 the highest production rate of $6.28 \mu \mathrm{g} \mathrm{Cl}^{-1} \mathrm{~h}^{-1}$ was measured, in December $1996 \mathrm{BSP}$ was very low with only $0.36 \mathrm{\mu g} \mathrm{C}^{-1} \mathrm{~h}^{-1}$ (Table 3 ).

\section{Grazing on bacteria}

In the 3 control experiments 0.02 to 0.08 FLB HNF $^{-1}$, with a mean of $0.06 \mathrm{FLB} \mathrm{HNF}^{-1}(\mathrm{SD}=0.02)$, were found in the fixed samples. The fact that this control value deviated from zero shows that the impression of the microscopical image is misinterpreted to a small degree. On some occasions the number of FLB per HNF did not show a linear increase with time at a constant rate, but the rate of increase decreased with time (Fig. 4). This indication for a potential underestimation of ingestion rates derived from linear regression analysis is discussed below. Calculation of linear regressions with the corrected values (see control experiments in 'Materials and methods') yielded ingestion rates from 2.2 to 26.5 bacteria $\mathrm{HNF}^{-1} \mathrm{~h}^{-1}$ (mean $=7.5$; Table 4). Clearance rates, calculated as ingestion rate divided by bacterial abundance, and grazing rates of HNF on bacteria, estimated on the basis of ingestion rates and HNF numbers, are shown in Table 4. Grazing rates on bacteria were very low, ranging from $3.15 \times 10^{5}$ to $1.89 \times 10^{7}$ bac-
Table 3. Abundance, biomass and production of heterotrophic bacteria in the Alte Donau. Numbers in parentheses denote $1 \mathrm{SD}$

\begin{tabular}{|lccc|}
\hline Date $\begin{array}{c}\text { Abundance } \\
\left(10^{6} \mathrm{cells} \mathrm{ml}^{-1}\right)\end{array}$ & $\begin{array}{c}\text { Biomass } \\
\left(\mu \mathrm{C} \mathrm{C}^{-1}\right)\end{array}$ & $\begin{array}{c}\text { Production } \\
\left(\mu \mathrm{C} \mathrm{C}^{-1} \mathrm{~h}^{-1}\right)\end{array}$ \\
\hline 28 Aug 95 & 4.71 & 79.3 & $6.28(0.83)$ \\
25 Sep 95 & 2.81 & 54.5 & $2.92(0.62)$ \\
8 Nov 95 & 4.42 & 65.5 & $1.90(0.74)$ \\
15 Dec 95 & 3.55 & 54.5 & $0.70(0.15)$ \\
11 Apr 96 & 2.03 & 34.0 & $1.89(0.86)$ \\
23 Apr 96 & 1.30 & 31.0 & $2.20(0.72)$ \\
21 May 96 & 1.72 & 29.0 & $0.75(0.42)$ \\
18 Jun 96 & 2.05 & 47.0 & $3.85(1.03)$ \\
24 Sep 96 & 2.04 & 48.5 & $1.90(0.30)$ \\
8 Oct 96 & 3.33 & 60.5 & $1.75(0.26)$ \\
5 Nov 96 & 2.39 & 68.7 & $1.61(0.38)$ \\
3 Dec 96 & 3.10 & 69.5 & $0.36(0.08)$ \\
\hline
\end{tabular}

teria $\mathrm{l}^{-1} \mathrm{~h}^{-1}$ (mean $=5.11 \times 10^{6}$; Table 4$)$. No statistical significant correlations between HNF grazing (ingestion and grazing rates, clearance rates) and other parameters (HNF and bacterial numbers and biomass, BSP and water temperature) could be detected $(p>0.05)$.

\section{DISCUSSION}

\section{HNF abundance and growth}

In the Alte Donau, HNF abundance was on average $5.8 \times 10^{2}$ cells $\mathrm{ml}^{-1}$ for all sampling locations (Table 1 ) with values fluctuating between $0.2 \times 10^{2}$ and $39.2 \times$ $10^{2}$ cells $\mathrm{ml}^{-1}$. In contrast, eutrophic to mesotrophic
Fig. 4, Four representative FLB uptake curves determined in short-term experiments. Data points represent the mean of triplicate samples, corrected with the value obtained in the control experiments. Error bars denote 1 standard deviation. Regression lines were calculated for the linear portion of the uptake curves, assuming that ingestion is zero at the starting point of the experiment (see 'Materials and methods')

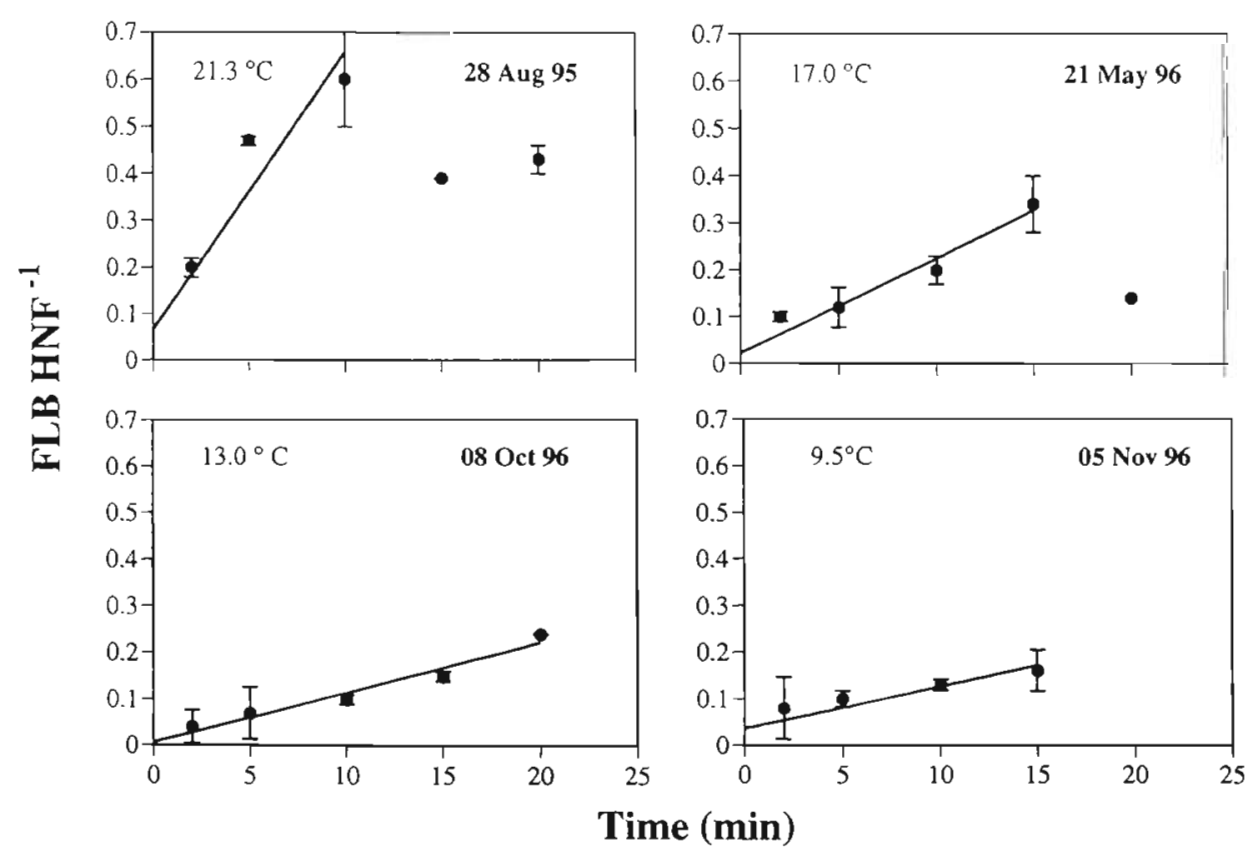


Table 4. Heterotrophic nanoflagellate ingestion rates, clearance rates, and grazing rates on bacteria, expressed as bacteria $\mathrm{l}^{-1} \mathrm{~h}^{-1}$, $\mu \mathrm{g} \mathrm{Cl}{ }^{1}$, and as percentage of bacterial secondary production (\% BSP) based on FLB uptake rates. BN:FLB = ratio of natural bacterial numbers and fluorescently labeled bacterial abundance

\begin{tabular}{|c|c|c|c|c|c|c|c|}
\hline \multirow[t]{2}{*}{ Date } & \multirow{2}{*}{$\begin{array}{l}\text { Water temp. } \\
\qquad\left({ }^{\circ} \mathrm{C}\right)\end{array}$} & \multirow[t]{2}{*}{ BN:FLB } & \multirow{2}{*}{$\begin{array}{c}\text { Ingestion rate } \\
\text { (bacteria HNF-1 } \mathrm{h}^{-1} \text { ) }\end{array}$} & \multirow{2}{*}{$\begin{array}{l}\text { Clearance rate } \\
\left(\mathrm{nl} H N F^{-1} \mathrm{~h}^{-1}\right)\end{array}$} & \\
\hline & & & & & $\left(10^{6}\right.$ bacteria $\left.\mathrm{l}^{-1} \mathrm{~h}^{-1}\right)$ & $\left(\mu g \mathrm{Cl}^{-1} \mathrm{~h}^{-1}\right)$ & $(\%$ BSP $)$ \\
\hline 28 Aug 95 & 21 & 4.7 & 17.6 & 3.7 & 17.8 & 0.36 & 5.8 \\
\hline 25 Sep 95 & 15 & 4.3 & 26.5 & 9.4 & 18.9 & 0.31 & 10.6 \\
\hline 8 Nov 95 & 2 & 4.2 & 8.9 & 2.0 & 5.8 & 0.11 & 5.6 \\
\hline 12 Dec 95 & 1 & 3.4 & 2.2 & 0.6 & 1.6 & 0.02 & 3.4 \\
\hline 11 Apr 96 & 8 & 4.3 & 3.5 & 1.7 & 1.6 & 0.03 & 1.7 \\
\hline 23 Apr 96 & 14 & 4.0 & 2.3 & 1.7 & 0.3 & 0.01 & 0.3 \\
\hline 21 May 96 & 17 & 4.0 & 6.2 & 3.6 & 1.6 & 0.03 & 4.2 \\
\hline 18 Jun 96 & 22 & 4.0 & 4.8 & 2.3 & 3.5 & 0.07 & 1.7 \\
\hline 24 Sep 96 & 12 & 4.3 & 3.4 & 1.7 & 2.1 & 0.04 & 1.9 \\
\hline 8 Oct 96 & 13 & 8.0 & 5.9 & 1.8 & 2.2 & 0.04 & 2.1 \\
\hline 5 Nov 96 & 9 & 4.7 & 3.3 & 1.4 & 2.5 & 0.04 & 2.8 \\
\hline 3 Dec 96 & 2 & 10.0 & 5.8 & 1.9 & 3.5 & 0.07 & 19.3 \\
\hline
\end{tabular}

freshwater systems display mean HNF densities of $10^{3}$ cells $\mathrm{ml}^{-1}$, with peak abundances of up to $10^{4}$ cells $\mathrm{ml}^{-1}$ (Nagata 1988, Bloem \& Bär-Gilissen 1989, Sanders et al. 1989, Fukami et al. 1991, Hansen \& Christoffersen 1995). Values as low as in the Alte Donau are rarely found in eutrophic systems (e.g. Pace et al. 1990), and are in the range of HNF abundances from oligotrophic systems (Sanders et al. 1992, Vaqué \& Pace 1992). As a consequence, the ratio of bacterial to HNF numbers was high, in the range of $3 \times 10^{3}$ to $9 \times$ $10^{3}$. According to Sanders et al. (1992), who analysed an extensive data set on the relation between bacterial and HNF abundance, this ratio should not significantly exceed $1 \times 10^{3}$ if $\mathrm{HNF}$ were to exert a strong grazing impact on heterotrophic bacteria.

Growth rates estimated by selective filtration were within the range for natural flagellate assemblages (Bloem \& Bär-Gilissen 1989, Weisse 1991, Carrick \& Fahnenstiel 1992, Hansen \& Christoffersen 1995), with slowest growth at low temperatures. Filtration through $10 \mu \mathrm{m}$ gauze does not completely exclude small ciliates which can prey on HNF, and HNF around $10 \mu \mathrm{m}$ might also ingest the smallest ones. However, the ciliate numbers in the size range $<10 \mu \mathrm{m}$ were negligible. Additionally, the fact that HNF mean cell volume did not change during all but 1 experiments indicated that the larger rells, when released from grazing pressure by organisms $>10 \mu \mathrm{m}$, did not grow at the expense of the smaller ones. On 30 July, the HNF compostion might have shifted to larger species, which still did not imply that these species fed on smaller ones. Experiments with filtered (Table 2) and unfiltered water (Fig. 3) allowed a conservative comparison between gross and net growth rates. The results indicated that HNF production in the water column was completely consumed by grazers and/or balanced by other mortality factors on 30 July and 23 October 1996 (Fig. 3). This is well in agreement with a number of other studies which demonstrated strong grazing pressure on the flagellate assemblage in freshwaters (Dolan \& Gallegos 1991, Weisse 1991, Jürgens \& Stolpe 1995, Cleven 1996). Top-down control seems to be the predominant factor in the regulation of HNF abundance (Gasol 1994, Gasol et al. 1995) especially in more nutrient rich systems.

Based on the data on HNF abundance and net growth, we could not expect a strong impact of these protozoans on the bacterial assemblage in our system, unless they were very efficient bacterivores.

\section{Grazing on bacteria}

Ingestion and clearance rates determined in this study are at the lower end of the values reported in the Iiterature (Fenchel 1982b, Sherr et al. 1986, Sanders et al. 1989, Weisse 1989, Vaqué \& Pace 1992), but lie well within the range of data obtained by FLB uptake experiments (Sherr et al. 1987. Bloem et al. 1989, Fukami et al. 1991, Simek \& Straškrabová 1992). The resulting grazing rates of HNF on bacteria were low, leading to a removal of 0.3 to $19.3 \%$ (mean $=5.0 \%$ ) of BSP (Table 4). All the FLB-uptake experiments conducted over the course of a year indicated that grazing by HNF is rather a negligible factor in controlling bacterial production and abundance in the Alte Donau. Within the frame of our study, this finding is a consequence of both the low HNF numbers in our system as well as the relatively low ingestion rates recorded in all experiments. The applied combination of formaldehyde fixation and DAPI staining led to a bright fluorescence of the HNF cells and allowed for their easy detection. Fixing the samples by the Lugol-formalin decoloration technique recommended by Sherr et al. 
(1988) gave the same results for cell counts and measurements as with formaldehyde fixation ( $p>0.95$ ). Fixation with a final concentration of $2 \%$ glutaraldehyde in combination with DAPI staining resulted in a very pale fluorescence and was thus not applied. Additionally, the fact that HNF might lose their flagella during the enumeration procedure was taken into account. So the potential error in determining HNF abundance is expected to be low, but there are several indications that the estimation of ingestion rates by FLB-uptake experiments could lead to biased results. In this context it has to be mentioned that all models to estimate in situ ingestion rates from FLB uptake curves assume all flagellates to be alike. In fact, they are different in size and feeding mode (Fenchel 1982a), and their species composition in situ changes quantitatively and qualitatively during the year (Sanders et al. 1989, Pernthaler et al. 1996), resulting in different conditions for every experiment. Furthermore, the method cannot detect the consumption of attached bacteria. FLB could be rapidly digested during the linear part of the uptake curve (McManus \& Fuhrman 1986, Sieracki et al. 1987) or fluorescence of ingested prey could become too weak to be noticed, thus leading to a decrease of particles visible in HNF food vacuoles despite constant ingestion rates. When the plateau of the uptake curve is reached, ingestion of FLB should be equilibrated by digestion/egestion (McManus \& Fuhrman 1986, Gonzales et al. 1990). At low temperatures an incubation time of $20 \mathrm{~min}$ might have been too short to reach the point of equilibrium. Yet we had no reason to assume that the rate of ingestion should increase after a certain time interval. As the estimation of ingestion rates was based on linear regression, the slope of the regression line should be constant regardless of the duration of the experiment. Additionally, particle egestion from food vacuoles could occur upon fixation, which would lead to a reduction of FLB countable in HNF cells (Sieracki et al. 1987). To account for this source of error, we conducted an experiment to compare the formaldehyde fixation with the Lugolformalin decoloration technique (Sherr et al, 1988). Resulting ingestion rates were not different $(p>0.50)$ for the 2 fixation methods, indicating that the potential error would remain unchanged irrespective of the fixative used. Finally protozoa possibly discriminate against heat-killed FLB in favor of live bacteria (Sherr et al. 1987, Landry et al. 1991). We observed that only part of the flagellate cells examined really contained FLB. The rest could be composed of non bacterivorous species and/or flagellates that just selected negatively for the fluorescent prey. All the considerations made above point out that ingestion rates derived from heat killed FLB uptake experiments may be underestimations. However, it is difficult to determine the degree of uncertainty. There are only a few studies which directly compare FLB-uptake experiments with other methods, which of course also have their shortcomings (Nygaard \& Hessen 1990, Pace et al. 1990, Landry et al. 1991, Vaque et al. 1992). The main trend is that methods observing the ingestion of tracer particles yield lower uptake values than methods which compare cell abundances in manipulated and unmanipulated samples (Vaqué et al. 1994).

In order to control bacterial abundance in an aquatic system, removal of bacterial cells by HNF grazing should be in the same range as, or even exceed, bacterial production at least temporarily during the year (Nagata 1988, Weisse 1989, Fukami et al. 1991). Even when integrating all error sources into our calculations, we did not obtain such high values. HNF ingestion rates would have had to be higher by a factor of 10 to 100 (mean 20) to account for $100 \%$ of the consumption of bacterial secondary production during the entire investigation period.

Yet, there is also ample evidence for discrepancy between HNF grazing and BSP in other studies (Sanders et al. 1989, Sherr et al. 1989, Pernthaler et al. 1996). In all these investigations bacterivory by HNF did not equal bacterial secondary production, but still contributed to bacterial mortality to a substantial extent. Grazing rates which were as low as the ones determined in our study were so far only confirmed by Vaqué \& Pace (1992) for Canadian lakes with HNF grazing rates being 1 order of magnitude lower than bacterial growth rates.

Ingesting bacteria with the calculated rates from Table 4, a flagellate would consume 0.03 to $0.44 \mathrm{pg}$ (mean $=0.14 \mathrm{pg}$ ) bacterial carbon, or 0.3 to $3.0 \%$ (mean $=1.1 \%$ ) of its own cell carbon content $\mathrm{h}^{-1}$. Using the calculated growth rates of Table 2 in regard to water temperature during every experiment, and assuming a growth efficiency for HNF of $40 \%$ (Caron \& Goldman 1990, Solić \& Krstulović 1994), it could be shown that bacterial carbon production always exceeded HNF carbon demand by 2.5 to 24 times, except for 3 December 1996 when BSP accounted for $82 \%$ of HNF carbon requirements. But despite this apparently abundant carbon source, HNF covered only an average of $20.9 \%$ of their carbon demand by grazing on bacteria. On 8 November 1995, $67 \%$ of HNF carbon requirements was met by consumption of bacteria, on 25 September 1995 the consumption of bacterial carbon made up about half $(60 \%)$ of HNF demand. On all other occasions their contribution varied between only 5 and $25 \%$ (Fig. 5). This implies that at the time of high contribution of bacteria to HNF carbon demand about 1.5 times higher ingestion rates would be required to balance HNF growth, while at times of low contribution ingestion rates are too low by a factor of 20 . On aver- 


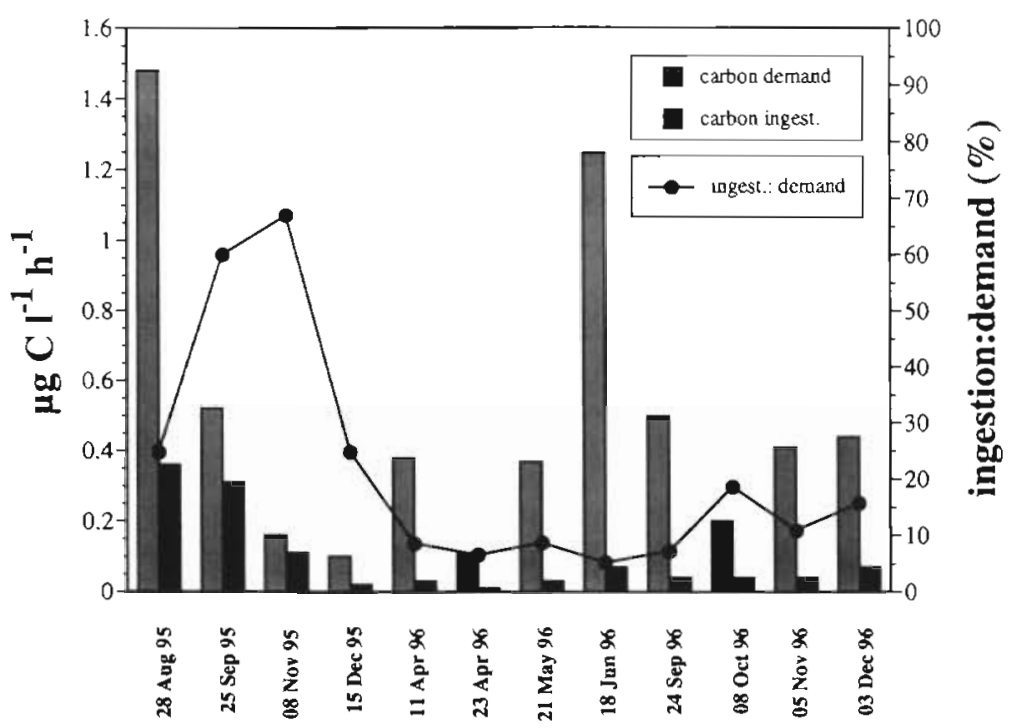

Fig. 5. Carbon demand of the heterotrophic nanoflagellate assemblage (grey columns), based on the generation times calculated in Table 2 (see text for details), carbon ingestion (black columns), based on FLB uptake experiments, and percentage of HNF requirements met by the ingestion of bacterial carbon (line)

age, HNF would have had to ingest 5 times more bacteria than calculated to meet their carbon demand.

\section{Implications for the pelagic carbon cycle}

It is evident from the present investigation that $\mathrm{HNF}$ abundance and ingestion rates were too low for the most part of the year to have the capacity to control bacterial production, even when severe underestimation of ingestion rates was taken into account. Factors other than HNF grazing must play an important role for the mortality of bacteria in the Alte Donau. A seasonal study on the quantification of energy fluxes through the microbial compartment and on bacterial morphotype succession conducted in the same system 1994/1995 (Kirschner et al. unpubl.) revealed that the bacterial assemblage was dominated by rod- (average: $53 \%$ ) and vibrio- (average: 36\%) shaped bacteria, which occurred alternately. The contribution of cocci was rather constant and made up on average $7 \%$ over the year. The contribution of filamentous forms amounted to $4 \%$, but showed distinct peaks in spring 1994 and 1995 of up to $19 \%$. During the major part of the year mean cell volumes were small, ranging from 0.035 to $0.063 \mu^{3}$. Mean cell volumes only increased to values from 0.116 to $0.173 \mu \mathrm{m}^{3}$ during the massive spring blooms of filamentous bacteria. It could be shown by principal component analysis that the dynamics of rods, vibrio and cocci was mainly determined by abiotic and bottom-up factors, while for fila- mentous bacteria top-down effects as well as competition were considered to be of major importance. The results of this analysis seem to be well in agreement with the present study. The role of mixotrophic flagellates was not evaluated by the methods employed in this investigation. Pigmented flagellates with ingested FLB were occasionally found during analysis of the FLB-uptake experiments, but their number was too low in order to contribute significantly to controlling bacterial numbers. Additionally, it has to be assumed that especially filamentous bacteria are not ingestable for them as well as for other small protozoans (Jürgens \& Güde 1994). Metazooplanktonic predators like cladocerans, which do have the potential to feed on filamentous forms as well, could be important bacterivores in the investigated system (Sanders et al. 1989, Jürgens $\&$ Stolpe 1995). Virus induced cell lysis is also assumed to be an important mortality factor. It has been shown that lysis by bacteriophages accounted for 30 to $40 \%$ of daily bacterial production in the investigated system (Fischer \& Velimirov unpubl.).

Another consequence of the fact that only a mean of $0.09 \mu \mathrm{g}$ bacterial carbon $\mathrm{l}^{-1} \mathrm{~h}^{-1}$ was consumed by HNF was that transfer of picoplanktonic carbon to higher trophic levels via HNF was negligible, even if nanoflagellates themselves were under strong predatory control. So in the Alte Donau HNF could not function

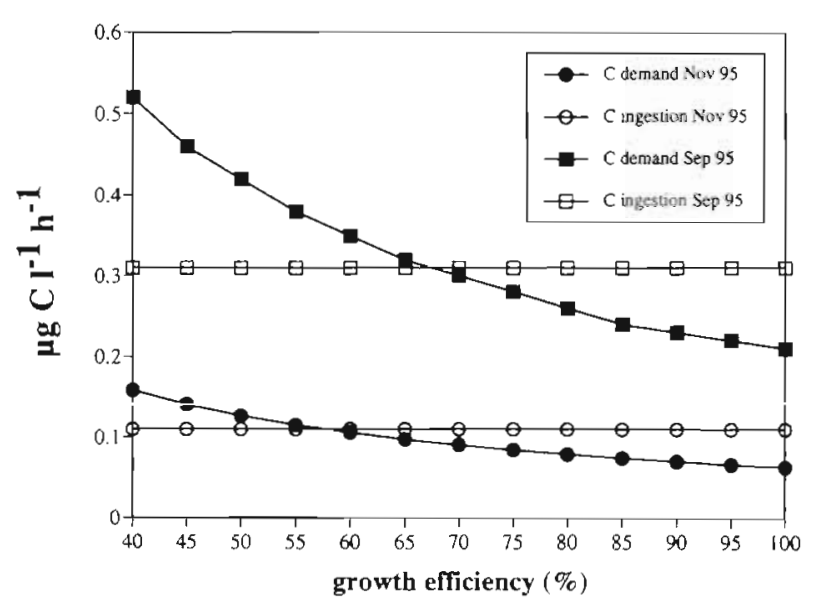

Fig. 6. HNF carbon demand calculated for increasing growth efficiency compared to HNF ingestion of bacterial carbon. Values are based on the data from Fig. 5. Where the 2 curves intersect, $C$ demand is balanced by $C$ ingestion. Such a balance would be reached with a growth efficiency of $65 \%$ in September and $54 \%$ in November 1995 
as a link between the microbial compartment and the classical pelagic food chain.

The contribution of HNF to bacterial grazing and bacterial carbon transfer has been the focus of many studies (Nagata 1988, Sherr et al. 1989, Carrick et al. 1991), and it is now evident that they do not always effectively control bacterial production (Gasol \& Vaqué 1993, Pace \& Cole 1996). However, less attention has been paid to the question whether HNF completely cover their carbon requirements by ingestion of bacteria (Jürgens 1992, Vaqué et al. 1992). The discrepancy between bacterial carbon production and bacterial carbon consumption by HNF in the investigated system may be explained by the uncertainties of the methods applied for such an estimation. In an attempt to test whether the increase of growth efficiency would lead to situations where ingestion of bacterial production could match HNF carbon demand, we assumed a carbon balance between HNF ingestion and production and calculated the corresponding growth efficiency for each month. In Fig. 6 it can be seen that such a balance would be reached for September and November 1995, with a growth efficiency of 65 and $54 \%$, respectively. For all other sampling periods the calculated growth efficiency was found to be well above $100 \%$ and therefore extremely unrealistic. This implied that despite all possible errors in estimating HNF growth rates, ingestion rates, and growth efficiency, and using biovolume to carbon conversion factors, we could not disregard the possibility that HNF had to tap additional carbon sources in order to maintain the obtained production levels. It was repeatedly shown that HNF graze on autotrophic picoplankton (APP), and that they may even positively select APP over heterotrophic bacteria (Nagata 1988, Pernthaler et al. 1996). During the FLBuptake experiments it was observed that 10 to $15 \%$ of the examined flagellates contained APP cells. This suggested that at least a small fraction of the HNF assemblage could complete its diet by ingesting picocyanobacteria. Additionally, it cannot be excluded that HNF prey upon other heterotrophic nanoplankton (Havskum \& Hansen 1997), although this is not indicated by our experiments. It is also known that nanoflagellates have the capability to clear the water for other particles than heterotrophic and autotrophic picoplankton. It has been shown that HNF graze on viruses and virus-sized particles (Gonzales \& Suttle 1993), however it remains questionable whether consumption of viruses can contribute to HNF feeding to a noteworthy extent. A remaining potential food source for HNF is dissolved organic matter (DOM). Flagellates can ingest a variety of macromolecules including carbohydrates and proteins (Sherr 1988, Tranvik et al. 1993, Christoffersen et al. 1996), but whether this mode of nutrition plays a significant role in natural sys- tems is not yet clear (Tranvik 1994). In the investigated system the contribution of DOM to HNF nutrition would have to amount to 30 to $80 \%$ in order to meet their carbon demand.

Acknowledgements. We are grateful to R. Psenner for advice concerning the FLB method, and to A. Steitz for making her data on autotrophic picoplankton available. We also want to thank T. Fenchel and M. G. Weinbauer for constructive criticism and valuable comments on the first version of the manuscript. This work was supported by a grant of the city of Vienna, MA 45 and special thanks are due to DI G. Ladinig.

\section{LITERATURE CITED}

Bloem J, Bär-Gilissen MJ (1989) Bacterial activity and protozoan grazing potential in a stratified lake. Limnol Oceanogr 34(2):297-309

Bloem J, Ellenbroek FM, Bär-Gilissen MJ, Cappenberg TE (1989) Protozoan grazing and bacterial production in stratified lake Vechten estimated with fluorescently labeled bacteria and by thymidine incorporation. Appl Environ Microbiol 55:1787-1795

Børshein KY, Bratbak G (1987) Cell volume to cell carbon conversion factors for a bacterivorous Monas sp. enriched from seawater. Mar Ecol Prog Ser 36:171-175

Caron DA, Goldman JC (1990) Protozoan nutrient regeneration. In: Capriulo GM (ed) The ecology of marine protozoa. Oxford University Press, New York, p 283-306

Carrick HJ, Fahnenstiel GL (1992) Growth and production of planktonic protozoa in Lake Michigan: in situ versus in vitro comparisons and importance to food web dynamics. Limnol Oceanogr 37(6):1221-1235

Carrick HJ, Fahnenstiel GL, Stoermer EF, Wetzel RG (1991) The importance of zooplankton-protozoan trophic couplings in Lake Michigan. Limnol Oceanogr 36(7): $1135-1345$

Christoffersen K, Bernard C, Ekebom J (1996) A comparison of the ability of different heterotrophic nanoflagellates to incorporate dissolved macromolecules. Arch Hydrobiol Spec Issues Adv Limnol 48:73-84

Cleven EJ (1996) Indirectly fluorescently labelled flagellates (IFLF): a tool to estimate the predation on free-living heterotrophic flagellates. J Plankton Res 18:429-442

Cole JJ, Caraco NF (1993) The pelagic food web of oligotrophic lakes. In: Ford TE (ed) Aquatic microbiology. Blackwell, Boston, p 101-111

del Giorgio PA, Gasol JM (1995) Biomass distribution in freshwater plankton communities. Am Nat 146:135-152

del Giorgio PA, Gasol JM, Vaqué D, Mura P, Agusti S, Duarte CM (1996) Bacterioplankton community structure: protists control net production and the proportion of active bacteria in a coastal marine community. Limnol Oceanogr 41(6):1169-1179

Dolan JR, Gallegos CL (1991) Trophic coupling of rotifers, microflagellates, and bacteria during fall months in the Rhode River Estuary. Mar Ecol Prog Ser 77:147-156

Ducklow HW, Carlson CA (1992) Oceanic bacterial production. Adv Microb Ecol 12:113-181

Fenchel T (1982a) Ecology of heterotrophic microflagellates. I. Some important forms and their funtional morphology. Mar Ecol Prog Ser 8:211-223

Fenchel T (1982b) Ecology of heterotrophic microflagellates. II. Bioenergetics and growth. Mar Ecol Prog Ser 8: $225-231$ 
Fukami K, Meier B, Overbeck J (1991) Vertical and temporal changes in bacterial production and its consumption by heterotrophic nanoflagellates in a north German eutrophic lake. Arch Hydrobiol 122:129-145

Gasol JM (1994) A framework for the assessment of top-down vs bottom-up control of heterotrophic nanoflagellate abundance. Mar Ecol Prog Ser 113:291-300

Gasol JM, Vaqué D (1993) Lack of coupling between heterotrophic nanoflagellates and bacteria: a general phenomenon across aquatic systems? Limnol Oceanogr 38(3): $657-665$

Gasol JM, Simons AM, Kalff J (1995) Patterns in the top-down versus bottom-up regulation of heterotrophic nanoflagellates in temperate lakes. J Plankton Res 17:1879-1903

Gonzales JM, Suttle CA (1993) Grazing by marine nanoflagellates on viruses and virus-sized particles: ingestion and digestion. Mar Ecol Prog Ser 94:1-10

Gonzales JM, Iriberri J, Egea L, Barcina I (1990) Differential rates of digestion of bacteria by freshwater and marine phagotrophic protozoa. Appl Environ Microbiol 56: $1851-1857$

Hansen B, Christoffersen K (1995) Specific growth rates of heterotrophic plankton organisms in a eutrophic lake during a spring bloom. J Plankton Res 17:413-430

Havskum H, Hansen AS (1997) Importance of pigmented and colourless nano-sized protists as grazers on nanoplankton in a phosphate-depleted Norwegian fjord and in enclosures. Aquat Microb Ecol 12:139-151

Hobbie JE, Dayley RJ, Jasper S (1977) Use of Nuclepore filters for counting bacteria by epifluorescence microscopy. Appl Environ Microbiol 33:1225-1228

Jürgens K (1992) Is there plenty of food for bacterivorous flagellates in eutrophic waters? Arch Hydrobiol Beih Ergeb Limnol 37:195-205

Jürgens K, Güde H (1994) The potential importance of grazing-resistant bacteria in planktonic systems. Mar Ecol Prog Ser 112:169-188

Jürgens K, Stolpe G (1995) Seasonal dynamics of crustacean zooplankton, heterotrophic nanoflagellates and bacteria in a shallow, eutrophic lake. Freshwat Biol 33:27-38

Jürgens K, Wickham SA, Rothhaupt KO, Santer B (1996) Feeding rates of macro- and microzooplankton on heterotrophic nanoflagellates. Limnol Oceanogr 41(8): $1833-1839$

Kirschner AKT, Velimirov B (1997) A seasonal study of bacterial community succession in a temperate backwater system, indicated by variation in morphotype numbers, biomass, and secondary production. Microb Ecol 34: $27-38$

Landry MR, Lehner-Fournier JM, Sundstrom JA, Fagerness VL, Selph KE (1991) Discrimination between living and heatkilled prey by a marine zooflagellate, Paraphysomonas vestita (Stokes). J Exp Mar Biol Ecol 146:139-151

Mathias CB, Kirschner AKT, Velimirov B (1995) Seasonal variations of virus abundanco and viral control of tho bac terial production in a backwater system of the Danube river. Appl Environ Microbiol 61:3734-3740

McManus GB, Fuhrman JA (1986) Bacterivory in seawater studied with the use of inert fluorescent particles. Limnol Oceanogr 31(2):420-426

Nagata T (1988) The microflagellate-picoplankton food linkage in the water column of Lake Biwa. Limnol Oceanogr $33(4): 504-517$

Norland S (1993) The relationship between biomass and volume of bacteria. In: Kemp PF, Sherr BF, Sherr EB, Cole JJ (eds) Current methods in aquatic microbial ecology. Lewis Publishers, Boca Raton, p 303-307
Nygaard $K_{1}$ Hessen DO (1990) Use of ${ }^{14} \mathrm{C}$-protein-labeled bacteria for estimating clearance rates by heterotrophic and mixotrophic flagellates. Mar Ecol Prog Ser 68:7-14

Pace ML, Cole JJ (1996) Regulation of bacteria by resources and predation tested in whole-lake experiments. Limnol Oceanogr 41(7):1148-1460

Pace ML, McManus GB, Findlay SEG (1990) Planktonic community structure determines the fate of bacterial production in a temperate lake. Limnol Oceanogr 35(4): $795-808$

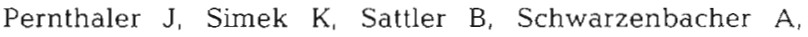
Bobkova J, Psenner R (1996) Short-term changes of protozoan control on autotrophic picoplankton in an oligomesotrophic lake. J Plankton Res 18:443-462

Porter KG, Feig YS (1980) The use of DAPI for identifying and counting aquatic microflora. Limnol Oceanogr 25(5): 943-948

Sachs L (1992) Angewandte Statistik. Anwendung statistischer Methoden. Springer, Berlin

Sanders RW, Porter KG, Bennett SJ, DeBiase AE (1989) Seasonal patterns of bacterivory by flagellates, ciliates, rotifers, and cladocerans in a freshwater planktonic community. Limnol Oceanogr 34(4):673-687

Sanders RW, Caron DA, Berninger UG (1992) Relationships between bacteria and heterotrophic nanoplankton in marine and fresh waters: an inter-ecosystem comparison. Mar Ecol Prog Ser 86:1-14

Sherr BF, Sherr EB, Andrew TL, Fallon RD, Newell SY (1986) Trophic interactions between heterotrophic protozoa and bacterioplankton in estuarine water analyzed with selective metabolic inhibitors. Mar Ecol Prog Ser 32:169-179

Sherr BF, Sherr EB, Fallon RD (1987) Use of monodipersed, fluorescently labeled bacteria to estimate in situ protozoan bacterivory. Appl Environ Microbiol 53:958-965

Sherr BF, Sherr EB, Rassoulzagedan F (1988) Rates of digestion of bacteria by marine phagotrophic protozoa: temperature dependence. Appl Environ Microbiol 54:1091-1095

Sherr BF, Sherr EB, Pedrós-Alió C (1989) Simultanous measurement of bacterioplankton production and protozoan bacterivory in estuarine water. Mar Ecol Prog Ser 54: $209-219$

Sherr EB (1988) Direct use of high molecular weight polysaccharide by heterotrophic flagellates. Nature 335:348-351

Sieracki ME, Haas LW, Caron DA, Lessard EJ (1987) Effect of fixation on particle retention by microflagellates: underestimation of grazing rates. Mar Ecol Prog Ser 38:251-258

Šimek K, Straškrabová V (1992) Bacterioplankton production and protozoan bacterivory in a mesotrophic reservoir J Plankton Res 14:773-787

Simon M, Azam F (1989) Protein content and protein synthesis rates of planktonic marine bacteria. Mar Ecol Prog Ser 51:201-213

Solić M, Krstulović N (1994) Role of predation in controlling bacterial and heterotrophic nanoflagellate standing stocks in the coastal Adriatic Sea: seasonal patterns. Mar Ecol Prog Ser 114:219-235

Tranvik L (1994) Effects of colloidal organic matter on the growth of bacteria and protists in lake water. Limnol Oceanogr 39(6): 1276-1285

Tranvik LJ, Sherr EB, Sherr BF (1993) Uptake and utilization of 'colloidal DOM' by heterotrophic flagellates in seawater. Mar Ecol Prog Ser 92:301-309

Van Looij A, Riemann B (1993) Measurement of bacterial production in coastal marine environments using leucine application of a kinetic approach to correct for isotope dilution. Mar Ecol Prog Ser $10297-1.04$

Van Wambeke F (1994) Influence of phytoplankton lysis or 
grazing on bacterial metabolism and trophic relationships. Microb Ecol 27:143-158

Vaqué D, Pace ML (1992) Grazing on bacteria by flagellates and cladocerans in lakes of contrasting food-web structure. J Plankton Res 14:307-321

Vaqué D, Pace ML. Findlay S, Lints D (1992) Fate of bacterial production in a heterotrophic ecosystem: grazing by protists and metazoans in the Hudson Estuary. Mar Ecol Prog Ser 89:155-163

Vaqué D, Gasol JM, Marrasé C (1994) Grazing rates on bacteria: the significance of methodology and ecological factors. Mar Ecol Prog Ser 109:263-274

Editorial responsibility: John Dolan,

Villefranche-sur-Mer, France
Velimirov B, Walenta-Simon M (1992) Seasonal change in specific growth rates, production and biomass of a bacterial community in the water column above a Mediterranean seagrass system. Mar Ecol Prog Ser 80:237-248

Weisse T (1989) The microbial loop in the Red Sea: dynamics of pelagic bacteria and heterotrophic nanoflagellates. Mar Ecol Prog Ser 55:241-250

Weisse $T$ (1991) The annual cycle of heterotrophic freshwater nanoflagellates: role of bottom-up versus top-down control. J Plankton Res 13:167-185

Zar JH (1974) Biostatistical analysis. Prentice Hall Inc, Englewood Cliffs, NY

Submitted: February 20, 1998; Accepted: August 10, 1998 Proofs received from author(s): March 31, 1999 